\title{
有馬產粘土の二三の性質
}

Some Properties of the Clay from Arima

柿谷 悟* (Satoru Kakitani)

1. 産状

六甲山地の北側山槐標高約 $300 \mathrm{~m}$ の高処飞温泉で有名な有馬町がある。東, 南, 西の三方は山に囲皇れ, 北は有馬川にそつて細長く谷状に開かれ, 三田 盆地につながつている。有馬町の北部，西方山田村方面には第三紀層が分布 し，七キエイソメン岩及びカコウ岩を被㠅している。上治寅治郎はての山田 第三紀層を中新統上部に属するものとした。有馬町より北に向い有馬川に沿 つて約 $3 \mathrm{~km}$ 山口村一带に相当公範囲に第三紀層に当る植物化石を含んだ粘 土層が約 $4 \mathrm{~m}$ 以上の厚さで分布している。実験に供した粘土は上山口村, 有熙川に沿つた道路の両側小高い丘で採集した。

\section{2. 示差熱分析}

表部に座する淡紶也粘士の示差熱分析の結果を第 1 浪に示す。 $170^{\circ} \mathrm{C} の$ と

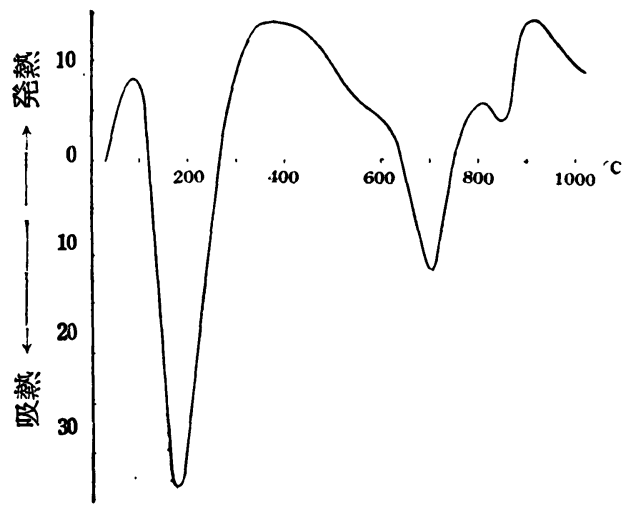

第 1 図 淡紅色粘土の示差熱分析曲線

ころに顕著な吸熱ピークが存 在し, $350^{\circ} \sim 400^{\circ} \mathrm{C} \oslash$ 間に 僅か儿緩い発熱があり, 次い で $700^{\circ} \mathrm{C}$ にはかなり大きい 吸熱ピークがでる。 $700^{\circ} \mathrm{C} \oslash$ 吸熱反応が終つてから再び $800^{\circ} \mathrm{C}$ を過ざると僅かではす るが, 吸熱反応がおてり，850 ${ }^{\circ} \mathrm{C}$ で極大を示し, 続いて急激 な発熱反念汇らつっている。 その極大は $910^{\circ} \mathrm{C}$ 附近にあ る。との示差熱分析曲線の挙

\footnotetext{
$*$ 大阪市立大学理工学部地学教室
} 
動はモンモリロン石の曲線とよく一致する。

\section{X 線趈 折}

この粘土を X 線延折計数装置で調べた。 $2 \theta$ が $5.55^{\circ}$, 格子面間隔になお

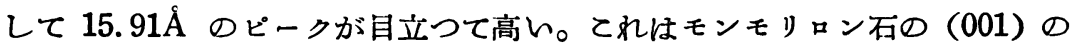
反射によるものと思 $5 。$

廷折結果を一括して第 1 表に示す。

第 1 表 有馬粘土の X 線廻折線

\begin{tabular}{|c|c|c|c|c|}
\hline 強度 & 格子面間 隔 & 備 & & 考 \\
\hline 40 & $15.91 \AA$ & M. & & \\
\hline 3 & 5.139 & & & \\
\hline 18 & 4.503 & M. & & \\
\hline 10 & 4.081 & A. & $\alpha-\mathrm{C}$. & \\
\hline 3 & 3.490 & A. & & \\
\hline 12 & 3.361 & Q. & & \\
\hline 8 & 3.223 & A. & & \\
\hline 4 & 3.066 & M. & & \\
\hline 3 & 2.947 & $\mathrm{~A}^{\cdot}$ & & \\
\hline 3 & 2.855 & A. & $\alpha-\mathrm{C}$. & \\
\hline 2 & 2.746 & A. & & \\
\hline 7 & 2.590 & A. & & \\
\hline 9 & 2.562 & M. & A. & \\
\hline 8 & 2.512 & A. & & \\
\hline 2 & 2.244 & M. & & \\
\hline 4 & 2.130 & Q. & & \\
\hline 4 & 1.828 & M. & Q. & \\
\hline 3 & 1.716 & M. & & \\
\hline 3 & 1.672 & M. & & \\
\hline 2 & 1.546 & M. & & \\
\hline 5 & 1.503 & M. & & \\
\hline 2 & 1.377 & M. & & \\
\hline
\end{tabular}

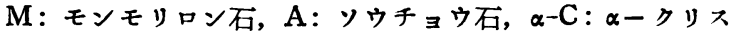
トバル石，Q：セキエイ。

この結果から有馬産粘土は主成分鉱物はモンモリロン石で不純物としてセ キエイ，チョウ石主にソウチョウ石が含まれてんることがわかる。低温型ク 
リストバル石はチョウ石の延折像と重複するので, 混入も一忍考えられるが 明らかでなん。

\section{4. 電子顕徽鏡観察}

粘土を蒸溜水に分散さし, 電子顕微鏡写真をとつた（涩版 I 写真 (1)）。と の写真で, 沙い粒子がんくつも重をって団塊をなしている部分もあるが, 非 常に浦くよく分散した粒子もまた見られる。しかし全体としてはもやもやし たモンモリロン石の形状を示している。ての粘土をらすんアンモニア水にひ たし，分散させたものを電子顕微鏡下でのぞくと見る見るうちと写真 (2) （図版 I ）に示すような米粒状の団塊が生成されて行く。図版 I 写真（3）は さらにそれを拡大したものである。まを Wyoming (U. S. A.) 産のモンモ リロン石及び Arizona（U. S. A.）産のモンモリロン石を同様に5すんア ンモニア水で処理して観察したとてろ，やはり同じよらな米粒状の団塊がだ きた。他の粘土鉱物（カオリナイト及びハロイサイト）を同じ方法で処理し， 観察したが，何等変化がみられなかった。有制粘土は最を容易にきれいな 米粒状団塊ができた。

\section{5. pH 及び凝固試験}

a） pHの測定 表部の淡紅色粘士及で下部の白色粘土をそれぞれリトマス 試験紙にのせ，蒸溜水を滴下したが，両粘土ともんちじるしん酸性を呈しな מつた。

キンヒドロン電極によつて $\mathrm{pH}$ を測定した結果は次のとおりでする。 淡紅色粘土………30 分後の安定した值

$$
\mathrm{pH}=5.00
$$

白色粘土

30 分後の值

$$
\mathrm{pH}=5.30
$$

1 時間 30 分後の安定した值

$$
\mathrm{pH}=5.20
$$

両粘土ともよく似を $\mathrm{pH}$ の值を示した。

b) 㓗固試験 $\mathrm{N} / 4 \odot \mathrm{NaCl} の$ 溶液 $100 \mathrm{cc}$ 中r試料 $1 \mathrm{~g}$ を入れ，よく振 とろした後静置し，48 時間後の凝固容積を測つた結果は次のとおりでする。 淡紅色粘土………2 cc 
白色粘土……………7 cc

豊順のベントナイト………16 cc（比較のため）

\section{6. 粘 性}

粘土の粘性につんては, 主として泥漿としての研究がなされているが，水

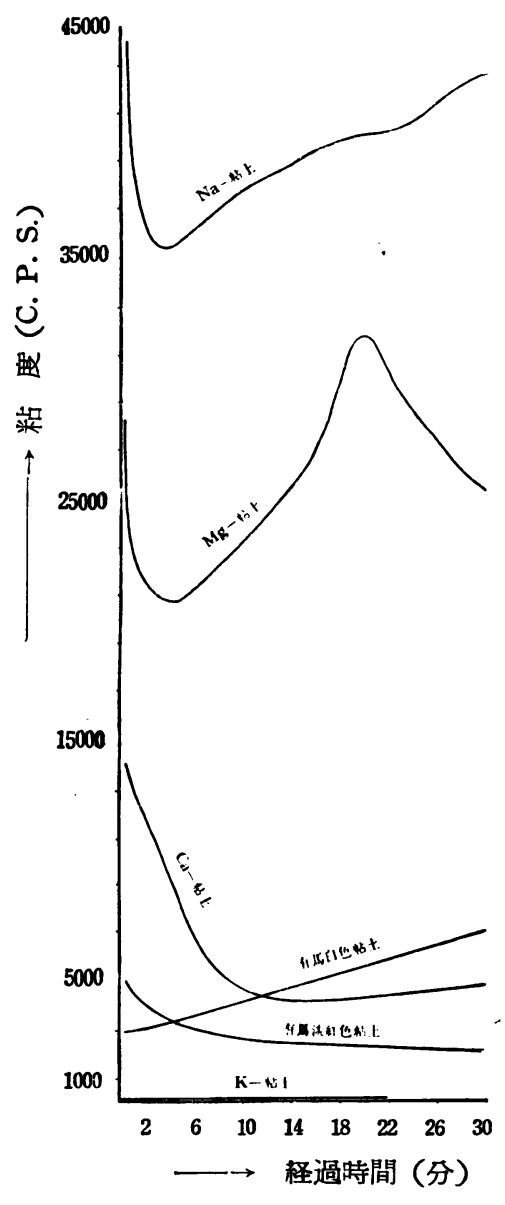

第 2 図 有馬粘土の粘性 分の含量の少ない粘土すをわち泥 漿にならない西る程度の可塑性を るつを粘土の粘性につんては余り 報告がないようで西る。そてでて の状態の淡紅色粘土及び白色粘土 の経過時間に伴ろ粘度の変化を, 東京計器製作所の製品, $\mathrm{B}$ 型粘度: 計を使用して調べた。まを粘土の 吸着イオンの違放粘性を大きく 支配することに着目し，薬品処理 によつて, K-粘土, Ca-粘土, $\mathrm{Mg}-$ 粘土, Na-粘土をつくり（粘土はん ホれる有馬産淡紅色粘土）粘度を

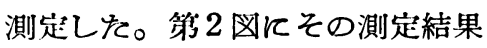
を示す。

$\mathrm{K}$-粘土, $\mathrm{Ca}$-粘土, $\mathrm{Mg}$-粘土の 各試料は $150 \mathrm{~g}$ 科量し, それ反蒸 溜水 $\left(20^{\circ} \mathrm{C}\right)$ を $150 \mathrm{cc}$ 加え, 磁製 乳鉢でよく混和し, 值ちに測定器 そ移して粘土の経過時間に上る変 化をみた。K一粘土は他のイオン 一粘土に較へて特別て低い值を示 し,さらさらした泥漿で時間的な 変化が湟とんどない。Ca-粘土は 12 分くらんまで低下し, それ以後 は一定する。 $\mathrm{Mg}$-粘土は 4 分位ま で急激な減少を示し，それ以後上昇して 20 分頃に極大がでる。 $\mathrm{Na}$-粘土は 
非常に粘度が大でての試料 $150 \mathrm{~g}$ 亿蒸溜水を $150 \mathrm{cc}$ 加えたのではかたくて 測定できす, 試料 $150 \mathrm{~g}$ 亿蒸溜水を $250 \mathrm{cc}$ 加えて測定した。これは 3 分く らんのとてろに極小ができ，てれょり徐ふに上梨する。

こてに各試料の 10 分後の粘度を一括して第 2 表に示す。

第 2 表 有馬粘土の粘性

\begin{tabular}{l|c|c} 
& 試料 + 蒸溜水 & 10 分後の粘度 (C. P. S.) \\
\cline { 1 - 2 } $\mathrm{Na}$ 一粘土 & $150 \mathrm{~g}+250$ c.c. & 38,000 \\
$\mathrm{Mg}$ 一粘土 & $150 \mathrm{~g}+150$ c.c. & 24,500 \\
$\mathrm{Ca}$ 一粘土 & $150 \mathrm{~g}+150$ c.c. & 4,700 \\
白色粘土 & $150 \mathrm{~g}+175$ c.c. & 4,200 \\
淡紅色粘土 & $150 \mathrm{~g}+150$ c.c. & 2,750 \\
$\mathrm{~K}$ 一粘土 & $150 \mathrm{~g}+150$ c.c. & 40 \\
\hline
\end{tabular}

同一の粘土であつても，吸着イオンの違いイよつて粘度に極端な差のある てとは，換言すればイオンと粘土鉱物との結合力に違んのあるてとを示して いると共に，これはまた粘土の利用という面からも興味のあるととと思ら。

\section{7. 吸着イオンの荤いによる格子面 (001) 間隔の变動}

吸着イオンの違いが粘度を大きく支配するととからモンモリロン石の層間 て入つたイオンと結晶層との結合力に差があるならば，(001）の格子面間隔 飞何等かの差が現われるのではないかとの予想のもとに，X 線迴折計数装置 を使用して各イオン一粘土の格子面 (001) 間隔の変動をみた。使用条件は次 のとおりである。

$15 \mathrm{~mA}, 40 \mathrm{kV}, \mathrm{Cu} \mathrm{K} \alpha$, Ni filter, 4-1-8, $1^{\circ}-1^{\circ}-0.1 \mathrm{~mm}$, scanning speed. $1 \% \mathrm{~min}$, chart speed $2 \mathrm{~cm} / \mathrm{min}$.

第 3 困にその結果を示す。

この四から备イオンの違いルよつて（001）のピークの高さに隨分差があ るととがわかると共に，僅かではするが格子面間隔に明膫な相異がでる。

ピークの高い方から順にならべると

$\mathrm{K}$ 一粘土, $\mathrm{Na}$ 一粘土, $\mathrm{Ca}$ 一粘土, $\mathrm{Mg}$ 一粘土 となる。

次に格子面 (001) 間隔の大きんるのから順にならべてみると， 


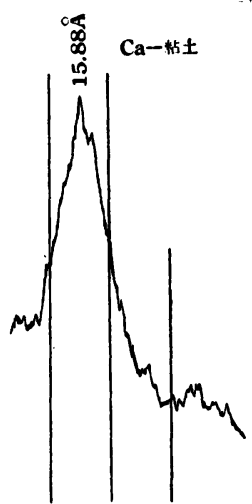

- $6^{\circ} 7^{\circ}$

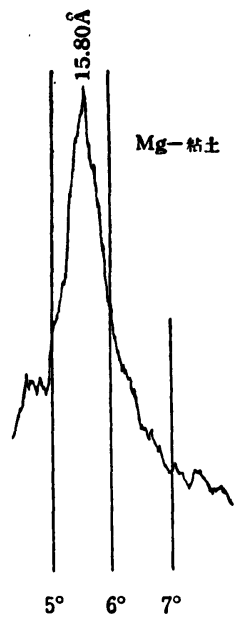

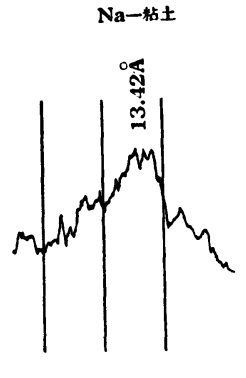

$5^{\circ} \quad 6^{\circ} \quad 7^{\circ}$

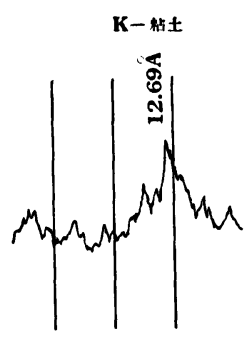

$\begin{array}{llll}5^{\circ} & 6^{\circ} & 7^{\circ} & 2 \theta\end{array}$

第 3 困 各種イオン一粘土の (001) ピーク

$2 \theta \quad$ (001) の格子面間隔
$\mathrm{Ca}$ 一粘土
$5.56^{\circ}$
$15.88 \AA$
$\mathrm{Mg}$ 一粘士
5.59
15.80
$\mathrm{Na}$ 一粘土
6.58
13.42
$\mathrm{K}$ 一粘土
6.96
12.69

となる。

以上のように, 吸着イオンの違いによつて, 䢙折線のピークの高さや, （001）の格子面間隔に明らかな違いを見出したが，てれと粘性との関係を直 接に結びつけるととは困難なようである。

\section{8. 結語}

ペントナイト, 酸性白土の産地は東日本, とくに山形, 新潟の両県に多く, 西日本には稀で西る。とてろがこて有馬は阪神の大都市に近接し，交通至便 であるにかかわらす，ての粘土の活用はてれまで多少試験的に使用されたて とがある程度で進んでいない。これは，堆積粘土であることてよると思われ るが, 多少の不純物を混入するために, 陶磁器原料としては多少不向をな点

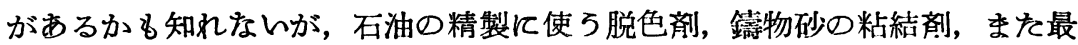
近注目を浴びている原子炉廃液の処理剈としての活用の途が開かれれば大い 
そ谷するとてろがあると思う。

有馬産粘土の性質を調へているろち，予期しなかつを結果も出て，その原 因を明らかにするてとはできなかつたが，一まず実験によつて知り得だ結果 をててに報告する。

終りに臨み，終始御指導御䩿鞋賜わりました大阪市立大学岩津潤教授に深 謝すると共に, 試料の採集に当り, 格別の御便宜:と御援助を恭けならした有 馬町, 炭酸温泉科学研究所々長山内勇吉氏飞感謝の意を表する。なお実験の 一部は当研究室の市原優子氏の協力を得を。こてて改めて謝意を述べる。

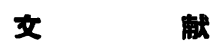

1）有馬温泉の研究（炭酸温泉科学研究所, 1954)

(1956 年 7 月 9 日受理)

\section{須藤俊男氏に31年度朝日文化觉}

昭和 31 年度の朝日賞の文化賞は 5 氏に授与されたが, そのうちの 1 人に東京教 育大学教授須藤俊男氏が選ばれた。授賞の対象となつた研究は,「火山物質起原の粘土 の鉣物学的研究」である。

周知の上ろに同氏の粘土鈗物の研究は, 戦前同氏が満洲の大陸科学院在籍中, chamosite の性状を明かにした当時に始まり，以来今日まで続けられ，特に戦後日本の 各種粘土の鉱物的性状の研究には同学の先頭に立ち，世界にわが国の粘土研究の成果 を認識させるに力を致した。中です氏の最近の顕著な功績として広く認められている るのは, 山口県蔵田鉱山のパイロフィライト鉣床から発見した長週期を有する粘士に 対して，その構造に対する概念を諸外国と殆んど時を同じくして始めて発表したこと， 及び，火山网起源のカォリン質粘土中にその生成過程を示す特異な栗いが状のボール (Sudo's ball) を発見したことであろろ。（岩生） 